\title{
5: $140996596-140980627$
}

National Cancer Institute

\section{Source}

National Cancer Institute. 5: 140996596-140980627. NCI Thesaurus. Code C42458.

Physical location of HDAC3_Gene 